\title{
$\therefore$ Association between Quality of Sleep and Body Mass Index: A Brief Narrative Review
}

\section{IJCRR}

Section: Healthcare

ISI Impact Factor

(2019-20): 1.628

IC Value (2019): 90.81

SJIF (2020) $=7.893$

\section{Darshana Nariya1, Subhash Khatri²}

'PhD Scholar, Nootan College of Physiotherapy, Gujarat, India; ${ }^{2}$ Principal Incharge, Nootan College of Physiotherapy, Gujarat, India.

(ब) (1) 8

Copyright@IJCRR

\section{ABSTRACT}

In the short term, a lack of adequate sleep can affect judgment, mood, ability to learn and retain information, and may increase the risk of serious accidents and injury. In the long term, chronic sleep deprivation may lead to a host of health problems including obesity, diabetes, cardiovascular disease, and even early mortality. These days, the treatment of sleep impediment speaks to a new challenge for health systems. So evaluation of factors affecting the quality of sleep has extreme significance. Previous studies have demonstrated the negative impact of high BMI on the quality of sleep. It was also stated that sleep deprivation is associated with obesity. Obesity and sleep disturbances are two major problems that adversely affecting the quality of life of humans worldwide. So this review aims to explore the association of Body Mass Index (BMI) with quality of sleep. Studies on the topic of quality of sleep and BMI will be reviewed so the findings of those articles will be used to explore the association between BMI and quality of sleep.

Key Words: Sleep quality, BMI, Obesity

\section{INTRODUCTION}

Sleep is defined simply as an absence of wakefulness. It is an active, regulated and metabolically different state needed for health and wellbeing. ${ }^{1,2}$ Normally, adults sleep about 7 to 9 hours per night. According to National Sleep Foundation, key determinants of good quality sleep are, ${ }^{3}$

- Sleeping more time while in bed (at least $85 \%$ t of the total time)

- Falling asleep in 30 minutes or less

- Waking up no more than once per night; and

- Being awake for 20 minutes or less after initially falling asleep.

The Pittsburgh Sleep Quality Index (PSQI) is a self-rated questionnaire that assesses sleep quality and disturbances. The score ranges from 0-21. A score of more than 5 indicates poor sleep quality. It has a reliability of 0.85 and a validity of $0.81 .4,5$

"Obesity is defined as anomalous or extreme fat accumulation that presents a health risk. A measure of obesity is the body mass index (BMI), a person's weight (in kilograms) divided by the square of his or her height (in meters)". A person with a BMI of thirty or additional is mostly thought of as obese. ${ }^{\circ}$ Prevelence of obesity in India is varies from $11.8 \%$ to $31.3 \%$. In Gujarat prevalence of obesity are $19.7 \%$ in males and $23.7 \%$ in females. ${ }^{7}$ So this review aims to explore the link between the quality of sleep and BMI.

\section{MATERIALS AND METHODS}

A computer-based literature search was done using the PUBMED, PUBMED CENTRAL, and GOOGLE SCHOLAR. Relevant articles with a full text published in English between the years 2011 to 2020 were screened and included. Editorials, Commentaries, Discussion papers, Conference abstracts, Reviews, and Duplicates were excluded. We included only cross-sectional studies with full-text articles. After the screening through articles, 7 relevant articles were included in the review. Figure 1 shows the searching strategy for this review. Characteristic of the reviewed article was summarized in table 1. All studies have examined the association between quality of sleep and BMI.

Out of 7 cross-sectional studies, 6 studies demonstrated that higher BMI is associated with poor quality of sleep

\section{Corresponding Author:}

Dr. Darshana Nariya, 168, Bhaktinagar-1, Varachcha, A.K. Road, Surat- 395008, Gujarat, India.

Mobile: 7984809693; Email id: darshananariya072@gmail.com

ISSN: 2231-2196 (Print)

Received: 04.09 .2020
ISSN: 0975-5241 (Online)

Revised: 12.11 .2021
Accepted: 02.01.2021
Published: 07.05.2021 
in adolescents, adults, older adults. Only one study demonstrated that there is no association between quality of sleep and BMI in long-lived subjects ( 870 participants, $\geq 90$ years $)(p=0.554) .5$ cross-sectional studies with a total of 20300 participants have demonstrated the association between sleep quality and BMI in the age group 16-54 years and found a significant association between sleep quality and BMI ( $p<0.05)$. One study in the age group $\geq 70$ years (719 participants) and found a signicant association between sleep quality and BMI $(\mathrm{p}<0.01)$. Our findings suggested that poor quality of sleep is significantly associated with high BMI.

\section{SUMMARY OF REVIEWED ARTICLES}

\section{Physiological basis for the link between BMI and quality of sleep}

This review evaluated the recent literature on the association between quality of sleep and BMI. The overall quality of sleep is significantly affected by increased BMI. As per the National Sleep Foundation, poor sleep quality is responsible for the abnormal increase in weight and abnormal increase in weight is responsible for the poor quality of sleep. Association between the quality of sleep and BMI seems to be caused by reduced levels of leptin (the hormone that suppresses appetite) and increased levels of ghrelin (the hormone that stimulates appetite) resulted from lack of sleep. These changes make a person eat more resulting in increased BMI. An abnormal increase in weight results in the accumulation of extra fat around the respiratory tract and obstruct the airway while sleeping leads to poor quality of sleep. ${ }^{3}$

\section{Association between the quality of sleep and BMI according to various age groups}

Age is the factor that can affect the association between quality of sleep and BMI. These findings are supported by studies done by Perla A. Vargas et al, Karl Petzer et al. Jun Wang et al. and Meena Mirdha et al. found a significant association of sleep quality and BMI in the age group of 16-34 years whereas Zhou yan et al. found no association in the age group of $\geq 90$ years. Although study done by Tamar Schochet et al. demonstrated a significant association in the age group of $\geq 70$ years. ${ }^{8-13}$

\section{Association between the quality of sleep and BMI according to gender}

Gender is another factor that can affect the association between quality of sleep and BMI. Jun wang et al. found that there was a significant association between sleep quality and BMI only in females not in males. ${ }^{10}$ Studies done by Vargas et al and Meena Mirdha et al. explained that only sleep disturbances are significantly associated with higher BMI. ${ }^{8,11}$
Association between duration of sleep and BMI

Shorter the duration of sleep, the greater the risk of being obese based on BMI. Tamar Schochet et al and Karl Petzer et al demonstrated that short sleep duration is significantly associated with higher BMI. ${ }^{9,12}$

\section{Association between sleep latency and BMI}

Sleep latency is the amount of time it takes to fall asleep. Sleep latency can also be affected by high BMI as demonstrated by Meena Mirdha et al. ${ }^{11}$ Chae Ryung Ha et al. suggested that high BMI tends to lower the quality of sleep. ${ }^{14}$

\section{CONCLUSION}

This narrative review explained that the poor quality of sleep is significantly associated with high BMI. Age and gender are the factors that found to affect the association of quality of sleep and BMI. As obesity is one of the major pandemics worldwide, there should be proper interventions to improve the quality of sleep and thereby reducing obesity and viceversa.

As objective measurement for the quality of sleep and obesity was not done in the studies included in this review, further research is needed with an objective assessment of the quality of sleep and obesity for better exploration of the relationship between quality of sleep and BMI.

\section{ACKNOWLEDGEMENT}

We acknowledged the scholars whose articles are included in references to this manuscript. We are also thankful to authors/editors/publishers of those articles and journals from where the literature for this article has been reviewed.

\section{REFERENCES}

1. Cooper CB, Neufeld EV, Dolezal BA, Martin JL. Sleep deprivation and obesity in adults: a brief narrative review. BMJ Open Sport Exerc Med 2018;4(1);1-5.

2. Carley DW, Farabi SS. Physiology of sleep. Diabetes Spectr. 2016;29(1):5-9.

3. National sleep foundation. What is good quality sleep? [Cited 2020 April 2]. Available from: https://www.sleepfoundation.org/ press-release/what-good-quality-sleep.

4. Buysse DJ, Reynolds CF, Monk TH. The Pittsburgh sleep quality index: a new instrument for psychiatric practice and research. Psychiatry Res 1989;28(2):193-213.

5. Backhaus J, Junghanns K, Broocks A, Riemann D, Hohagen F. Test-retest reliability and validity of the Pittsburgh Sleep Quality Index in primary insomnia. J Psychosom Res 2002;53(3):73740.

6. WHO. Obesity and Overweight. [Cited 2020 April 2]. Available from: https://www.who.int/news-room/fact-sheets/detail/ obesity-and-overweight. 
7. Ahirwar R, Mondal PR. Prevalence of obesity in India: a systematic review. Diabetes Metab Syndr 2019;13(1):318-21.

8. Vargas PA, Flores M, Robles E. Sleep quality and body mass index in college students: the role of sleep disturbances. J Am Coll Health 2014;62(8):534-41.

9. Peltzer K, Pengpid S. Sleep duration, sleep quality, body mass index, and waist circumference among young adults from 24 low-and middle-income and two high-income countries. Int J Environ Res Public Health 2017;14(6):566.

10. Wang J, Chen Y, Jin Y, Zhu L, Yao Y. Sleep quality is inversely related to body mass index among university students. Rev Assoc Med Bras 2019;65(6):845-50.

11. Mirdha M, Nanda R, Sharma HB, Mallick HN. Study of Association between Body Mass Index and Sleep Quality among Indian
College Students. Indian J Physiol Pharmacol 2019;63(1):8-15.

12. Shochat T, Shefer-Hilel G, Zisberg A. Relationships between body mass index and sleep quality and duration in adults 70 years and older. Sleep Health 2016;2(4):266-71.

13. Yan Z, Chang-Quan H, Zhen-Chan L, Bi-Rong D. Association between sleep quality and body mass index among Chinese nonagenarians/centenarians. Age 2012;34(3):527-37.

14. Ha CR, Kim SH, Na SB, You JS, Chang KJ. Advances in Experimental Medicine and Biology. Taurine 9. In: Marcinkiewicz J., Schaffer S. editors. The Association among Dietary Taurine Intake, Obesity and Quality of Sleep in Korean Women. 2015;803:725-733.

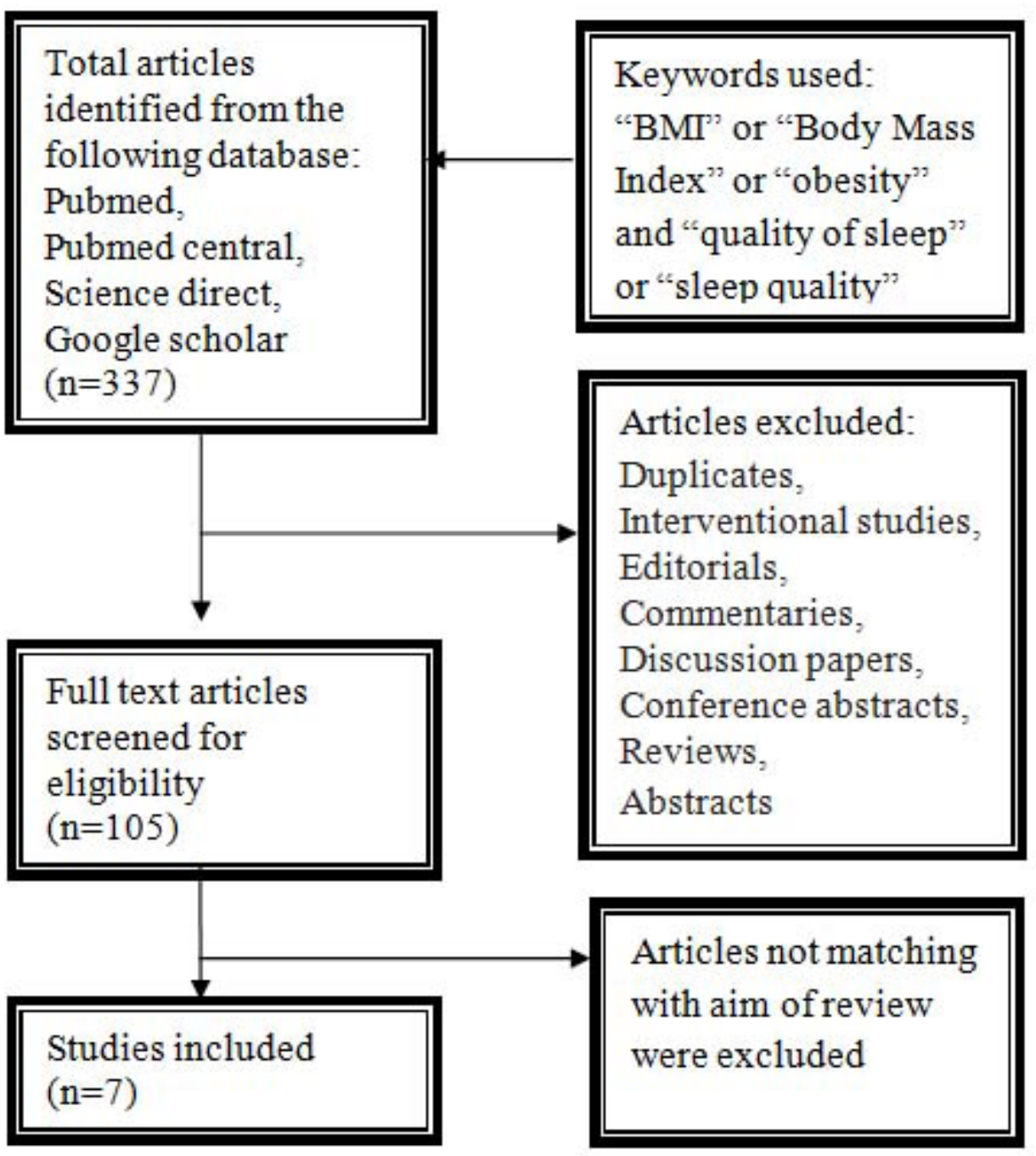

Figure 1: Searching strategy: Total 337 articales were identified from computer based literature search. After excluding the dupliates, interventional studies, editorials, commentaries, discussion papers, conference abstracts, reviews and abstracts 105 full text articles were screened. Out of that, only 7 articles were included as matched with the aim of this review. 
Table 1: Summary table of reviewed articles

\begin{tabular}{|c|c|c|c|c|c|}
\hline $\begin{array}{l}\text { Author/ } \\
\text { year of publication }\end{array}$ & Aim/purpose & $\begin{array}{l}\text { Research } \\
\text { design }\end{array}$ & $\begin{array}{l}\text { Sample charac- } \\
\text { teristics }\end{array}$ & $\begin{array}{l}\text { Outcome } \\
\text { measures }\end{array}$ & Key findings \\
\hline 1.Vargas PA et al. ${ }^{8}$ & $\begin{array}{l}\text { To explore the re- } \\
\text { lationship between } \\
\text { BMI and sleep pat- } \\
\text { tern, duration and } \\
\text { disturbances. }\end{array}$ & Cross-sectional & $\begin{array}{l}\text { The total sample } \\
\text { of } 515 \text { with age } \\
\text { group 18-34 years }\end{array}$ & PSQI, BMI & $\begin{array}{l}\text { Sleep disturbances were } \\
\text { associated with overweight } \\
\text { ( } \mathrm{p}=0.006 \text { ). There was a } \\
\text { small interaction effect } \\
\text { between age and sleep } \\
\text { disturbance. Suggesting } \\
\text { that sleep disturbances } \\
\text { may become more serious } \\
\text { with age ( } 3 \% \text { increase per } \\
\text { year of age) }\end{array}$ \\
\hline 2.Peltzer K et al. ${ }^{9}$ & $\begin{array}{l}\text { To explore the re- } \\
\text { lationship between } \\
\text { BMI, waist circum- } \\
\text { ference and sleep } \\
\text { pattern including } \\
\text { duration and distur- } \\
\text { bances. }\end{array}$ & Cross-sectional & $\begin{array}{l}\text { The total sample } \\
\text { of } 18211(42.1 \% \\
\text { male and } 57.9 \% \\
\text { female) with age } \\
\text { group } 16-30 \text { years }\end{array}$ & $\begin{array}{l}\text { BMI, waist } \\
\text { circumference, } \\
\text { sleep quality, } \\
\text { sleep duration, } \\
\text { physical activity, } \\
\text { and depression. }\end{array}$ & $\begin{array}{l}\text { Short sleep duration was } \\
\text { positively associated with } \\
\text { BMI in both males and } \\
\text { females. }\end{array}$ \\
\hline 3.Wang J et al. ${ }^{10}$ & $\begin{array}{l}\text { To investigate the } \\
\text { prevalence of over- } \\
\text { weight and obesity } \\
\text { and its association } \\
\text { with sleep quality in } \\
\text { university students } \\
\text { from the anhi prov- } \\
\text { ince in china. }\end{array}$ & Cross-sectional & $\begin{array}{l}470 \text { males and } \\
858 \text { females with } \\
\text { age group 19-23 } \\
\text { years }\end{array}$ & PSQI, BMI & $\begin{array}{l}\text { A significant correlation } \\
\text { ( } \mathrm{p}=<0.001 \text { ) found between } \\
\text { quality of sleep and BMI in } \\
\text { females. }\end{array}$ \\
\hline 4.Mirdha M et al." & $\begin{array}{l}\text { To examine the as- } \\
\text { sociation between } \\
\text { BMI and sleep qual- } \\
\text { ity among Indian } \\
\text { college students. }\end{array}$ & Cross-sectional & $\begin{array}{l}\text { The total sample } \\
\text { of } 230 \text { with age } \\
\text { group 18-24 years. }\end{array}$ & PSQI, BMI & $\begin{array}{l}\text { Sleep latency }(\mathrm{p}=0.038) \\
\text { and sleep disturbances } \\
(\mathrm{p}=0.03) \text { are associated } \\
\text { significantly with BMI. }\end{array}$ \\
\hline 5.Shochat $\mathrm{T}$ et al. ${ }^{12}$ & $\begin{array}{l}\text { To examine the re- } \\
\text { lationship between } \\
\text { BMI, sleep qual- } \\
\text { ity and duration in } \\
\text { older adults. }\end{array}$ & Cross-sectional & $\begin{array}{l}\text { The total sample } \\
\text { of } 719 \text { with an age } \\
\text { group } \geq 0 \text { of } 70\end{array}$ & PSQI, BMI & $\begin{array}{l}\text { Increased BMI is associ- } \\
\text { ated with short sleep } \\
\text { duration and low sleep } \\
\text { efficiency compare to } \\
\text { normal }\end{array}$ \\
\hline 6.Yan Z et al. ${ }^{13}$ & $\begin{array}{l}\text { To examine the as- } \\
\text { sociation between } \\
\text { sleep quality and } \\
\text { BMI in long-lived } \\
\text { subjects }\end{array}$ & Cross-sectional & $\begin{array}{l}216 \text { males and } 444 \\
\text { females with age } \\
\geq 90 \text { years }\end{array}$ & $\begin{array}{l}\text { Pittsburgh sleep } \\
\text { quality (PSQI) } \\
\text { index, BMI }\end{array}$ & $\begin{array}{l}\text { There is no association } \\
\text { between quality of sleep } \\
\text { and BMI }(\mathrm{P}=0.554) \text { in } \\
\text { long-lived subjects. }\end{array}$ \\
\hline 7.Ha CR et al. ${ }^{14}$ & $\begin{array}{l}\text { To investigate the } \\
\text { relationship be- } \\
\text { tween dietary tau- } \\
\text { rine intake, obesity } \\
\text { and quality of sleep } \\
\text { in Korean women }\end{array}$ & Cross-sectional & $\begin{array}{l}\text { The total sample } \\
\text { of } 16 \text { with age } \\
\text { group 30-55 years }\end{array}$ & $\begin{array}{l}\text { Korean sleep } \\
\text { scale, BMI }\end{array}$ & $\begin{array}{l}\text { High BMI tends to lower } \\
\text { the quality of sleep. }\end{array}$ \\
\hline
\end{tabular}

